\title{
Transmisi Volatilitas antara Nilai Tukar dan Indeks Harga Saham Gabungan di Pasar Finansial Indonesia: Analisa Setelah Krisis Finansial Asia 1997
}

\author{
Anhar Fauzan Priyono \\ Arief Bustaman \\ Fakultas Ekonomi dan Bisnis Universitas Padjajaran, Bandung, Indonesia \\ Email: fauzan@fe.unpad.ac.id
}

\begin{abstract}
Volatility of Indonesia Rupiah and Jakarta Composite Index remain one of main issues in Indonesia economy after 1997 Asian crisis. The objectives of this research are (1) determining the volatility of Indonesia Rupiah to US Dollar exchange rates and Jakarta Composite Index (JCI) and (2) analysing the dynamic volatility transmission between exchange rates and JCI. Exchange rate and JCI volatility were measured using $G A R C H(1,1)$ approach. Estimated using VAR model, this study found that current volatility of exchange rate (ER) respond significantly to the change of volatility of Jakarta Composite Index (JCI) in the previous 2 months. On the other hand, contribution of JCI volatility to ER is greater than $E R$ volatility to JCI, supporting the portfolio balanced theory.
\end{abstract}

Keywords: Indonesia financial market, volatility, GARCH(1,1), Vector Autoregression

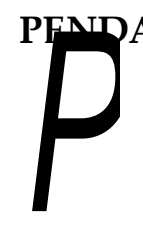

\section{AHULUAN}

esatnya integrasi ekonomi Indonesia dengan ekonomi dunia dalam dekade terakhir dan penerapan sistem nilai tukar mengambang pada tahun 1997 telah meningkatkan kerentanan ekonomi domestik terhadap guncangan eksternal. Dua variabel finansial yang sering terkena dampak eksternal adalah nilai tukar dan Indeks Harga Saham Gabungan (IHSG). Ilustrasi berikut menggambarkan nilai tukar Rupiah terhadap US Dollar dan pergerakan IHSG dari September 1999 sampai Desember 2016. Periode krisis Asia tahun 1997 dan subprime mortgage tahun 2008, ditandai dengan depresiasi Rupiah dan jatuhnya IHSG. 


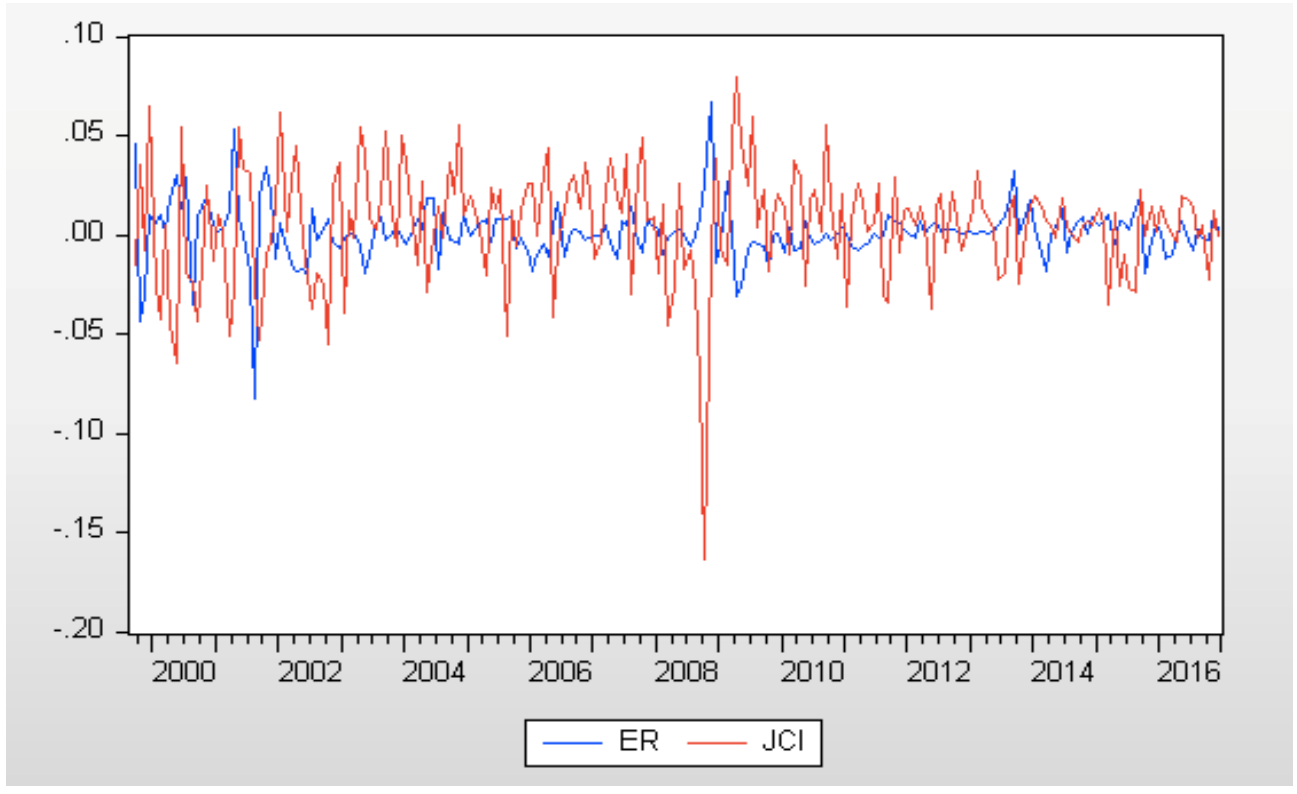

Sumber: Perhitungan penulis

Gambar 1. Pertumbuhan Nilai Tukar IDR/US\$ (ER) dan Pertumbuhan IHSG (JCI).

Selanjutnya, selain menggambarkan hubungan di antara dua variabel tersebut, grafik di atas juga menunjukkan bahwa baik nilai tukar dan IHSG memiliki indikasi volatilitas yang tinggi setelah 1997. Volatilitas dari dua variabel tersebut tidak diinginkan setidaknya untuk dua alasan: a) pada tingkat makro, kondisi tersebut adalah tanda dari risiko negara, b) di tingkat mikro, hal tersebut mengganggu pembuat kebijakan serta investor. Dengan demikian, mengingat fakta bahwa Indonesia diperkirakan akan semakin terintegrasi dengan pasar keuangan dunia, sangat penting untuk menganalisis transmisi volatilitas antara nilai tukar dan indeks saham.

Beberapa studi sebelumnya mengenai hubungan antara nilai tukar dan pergerakan harga saham telah dilakukan. Chiang, Yang \& Wang (2000) memanfaatkan bivariate conditional variance GARCH $(1,1)$, menganalisis return saham di negara-negara Asia dan interaksinya dengan perubahan kurs mata uang asing. Mereka menemukan bahwa nilai mata uang domestik berhubungan positif terhadap return saham domestik. Di sisi lain, mereka menyimpulkan bahwa faktor-faktor regional dan dunia, ditunjukkan oleh return saham Jepang dan Amerika Serikat, masing- masing, memiliki efek positif pada return saham di Asia.

QE Journal | Vol.06 - No. 03 December 2017 - 158 
Caporale, Pittis \& Spagnolo (2002) memanfaatkan GARCH - BEKK untuk menguji kausalitas varians dari hubungan antara volatilitas harga saham dan nilai tukar di empat negara Asia Timur. Mereka menemukan bahwa harga saham berpengaruh negatif terhadap nilai tukar di Jepang dan Korea Selatan, saat sebelum krisis, sedangkan di Indonesia dan Thailand, hubungannya adalah positif. Yang \& Doong (2004) mengeksplorasi mekanisme transmisi pergerakan rata-rata dan volatilitas antara saham dan pasar valuta asing untuk negara G-7. Mereka menemukan bukti yang mendukung efek asimetris dalam eksternalitas dari volatilitas, dan menunjukkan bahwa pergerakan harga saham akan mempengaruhi pergerakan nilai tukar di masa depan. Di sisi lain, perubahan masa depan harga saham kurang dipengaruhi oleh perubahan nilai tukar.

Berbeda dengan studi-studi di atas, Morales \& O'Donnell (2006) menemukan adanya eksternalitas volatililas antara pasar saham dan nilai tukar di semua pasar Asia Timur, kecuali Taiwan. Mereka menyimpulkan bahwa sejak krisis keuangan Asia, investor dan manajer portofolio dapat secara signifikan melakukan diversifikasi asset mereka antara saham dan mata uang.

Dengan demikian, berdasarkan penelitian-penelitian empiris terdahulu, dan, mengingat fakta bahwa Indonesia diperkirakan akan semakin terintegrasi dengan pasar keuangan dunia, akan menjadi sangat penting untuk menganalisis transmisi volatilitas antara nilai tukar dan indeks saham.

Tujuan dari penelitian ini adalah sebagai berikut: (1) Melakukan estimasi atas volatilitas atas nilai tukar dan Indeks Harga Saham Gabungan (IHSG), dan (2) Menganalisis dinamika transmisi volatilitas antara nilai tukar dan IHSG.

\section{METODE PENELITIAN}

Data yang digunakan dalam penelitian ini adalah nilai tukar Rupiah atas US Dollar dan Indeks Harga Saham Gabungan. Sedangkan periode observasi yang dipilih adalah bulan September 1999 - Desember 2016, yang dipantau dalam frekuensi bulanan.

Alasan pemilihan periode observasi tersebut diatas adalah mempertimbangkan dinamika krisis moneter, krisis finansial, penerapan 
floating exchange rate, dan beberapa guncangan atas harga minyak dunia, juga harga-harga komoditas dunia, serta mempertimbangkan tindakan pemerintah-pemerintah di dunia dalam menghadapi krisis global.

Data Indeks Harga Saham Gabungan bersumber dari Yahoo Finance. Nilai tukar Rupiah atas US Dollar diperoleh dari Pacific Exchange Rate Service.

Berikut adalah statistik deskriptif variabel pertumbuhan nilai tukar (ER), pertumbuhan IHSG (JCI), dan pertumbuhan Jumlah Uang Beredar (MS):

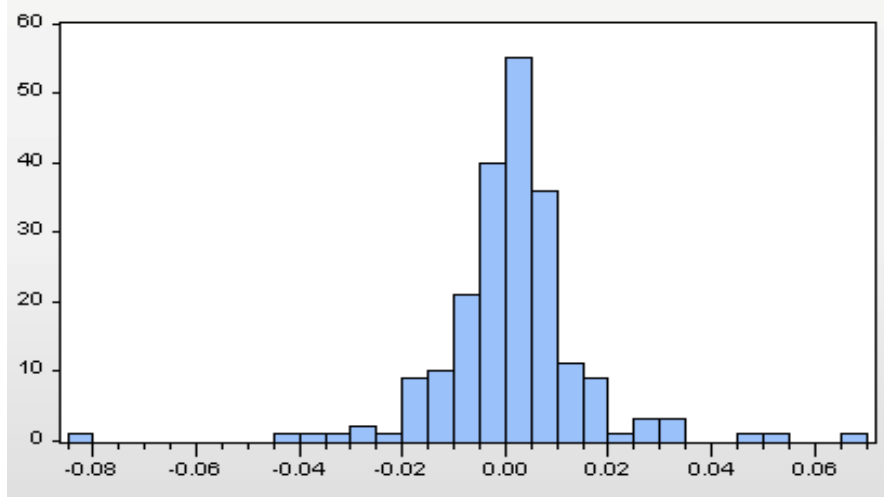

\begin{tabular}{lr} 
Series: ER \\
Sample 1999M09 $2016 \mathrm{M} 12$ \\
Observations 208 \\
Mean & 0.001235 \\
Median & 0.001137 \\
Maximum & 0.066505 \\
Minimum & -0.082189 \\
Std. Dev. & 0.014065 \\
Skewness & -0.333374 \\
Kurtosis & 11.65732 \\
& \\
Jarque-Bera & 653.4120 \\
Probability & 0.000000 \\
\hline
\end{tabular}

Sumber: Perhitungan penulis

Gambar 2. Statistik Deskriptif Pertumbuhan Nilai Tukar Rupiah atas US Dollar (ER).

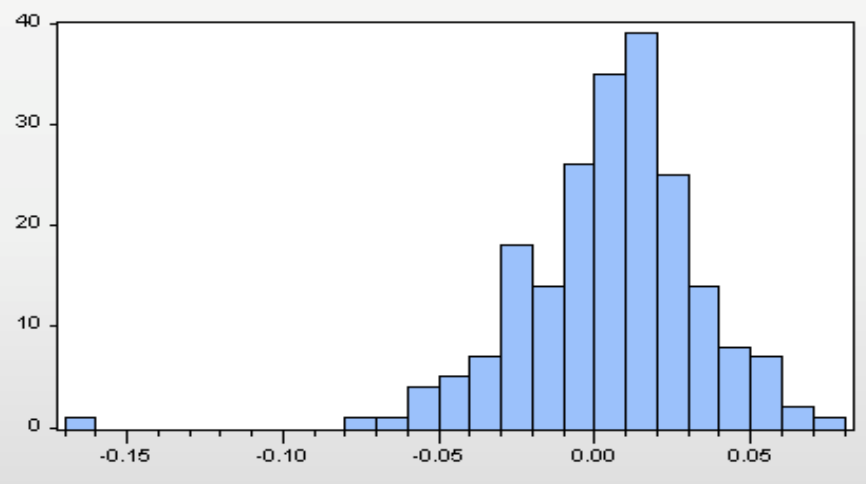

\begin{tabular}{ll}
\hline Series: JCl \\
Sample 1999M09 2016M12 \\
Observations 208 \\
Mean & 0.004861 \\
Median & 0.007515 \\
Maximum & 0.079657 \\
Minimum & -0.163815 \\
Std. Dev. & 0.028714 \\
Skewness & -1.072943 \\
Kurtosis & 7.971551 \\
& \\
Jarque-Bera & 254.1166 \\
Probability & 0.000000
\end{tabular}

Sumber: Perhitungan penulis

Gambar 3. Statistik Deskriptif Pertumbuhan IHSG (JCI).

Berdasarkan kedua statistik deskriptif diatas, maka dapat disimpulkan bahwa kedua variabel pertumbuhan tersebut memiliki kondisi lepto-kurtic, 
dimana nilai kurtosis yang melebihi batas normal yaitu 3, dan nilai statistik Jarque-Bera yang signifikan. Signifikansi nilai statistik Jarque-Bera tersebut menolak hipotesis bahwa data berdistribusi normal. Keadaan ini menunjukkan bahwa kemungkinan adanya permasalahan heteroskedastisitas akan menjadi besar. Dengan perkataan lain, data dari kedua variabel tersebut mengalami kondisi volatility clustering.

Penelitian ini dilakukan untuk menganalisa hubungan diantara variabelvariabel finansial, yaitu volatilitas nilai tukar (VER) dan volatilitas Indeks Harga Saham Gabungan (VJCI). Teknik pemodelan Vector Autoregression (VAR) kemudian akan dimanfaatkan untuk mempelajari hubungan saling mempengaruhi diantara ketiga variabel tersebut.

Sebelum dilakukan estimasi dengan model VAR, maka volatilitas dari ketiga variabel tersebut akan dihitung nilainya dengan memanfaatkan teknik pemodelan volatilitas. Teknik pemodelan volatilitas yang dipergunakan dalam penelitian ini adalah model $\operatorname{GARCH}(1,1)$. Setelah melakukan pengujian akar unit atas tiap variabel, dengan memanfaatkan teknik Augmented Dickey Fuller (ADF) test, dan menentukan tingkat kelambanan optimal untuk 2 model autoregressive (untuk 2 variabel - nilai tukar dan Indeks Harga Saham Gabungan) dengan memanfaatkan correlogram, maka volatilitas atas tiap variabel tersebut diestimasi dengan memanfaatkan kedua teknik pemodelan volatilitas diatas.

Selanjutnya, volatilitas dari tiap variabel yang didapatkan dari estimasi pemodelan $\operatorname{GARCH}(1,1)$ tersebut akan dimanfaatkan dalam skema VAR.

\section{Heteroskedastisitas}

Dengan mempertimbangkan persamaan struktural sebagai berikut:

$$
y_{t}=\alpha_{n}+\alpha_{1} x_{1 t}+\alpha_{2} x_{2 t}+e_{t}
$$

dan $e_{t} \sim N\left(0, \sigma_{e}^{2}\right)$

Maka kondisi homoskedastisitas dapat dicapai dengan:

$\operatorname{Var}\left(\widehat{e_{t}}\right)=\sigma_{e}^{2}$

Apabila variasi dalam residual tidak konstan, maka kondisi tersebut dinamakan heteroskedastisitas. Implikasi dari kondisi tersebut adalah QE Journal |Vol.06 - No. 03 December 2017 - 161 
standard error yang tidak tepat. Variabel-variabel finansial tidak dapat secara langsung diduga memiliki variasi yang tetap antar waktu. Dalam konsep finansial, kondisi heteroskedastisitas ini dikenal dengan istilah volatility clustering.

Pemanfaatan model yang tidak mengasumsikan variasi yang konstan antar waktu adalah upaya dalam menjawab permasalahan heteroskedastisitas. Dengan memperhatikan definisi atas variasi residual sebagai berikut:

$$
\sigma_{s t}^{2}=\operatorname{Var}\left(e_{t} \mid e_{t-1}, e_{t-2}, \ldots . .\right)=E\left\{\left(e_{t}-E\left(e_{t}\right)\right)^{2} \mid e_{t-1}, e_{t-2}, \ldots . .\right.
$$

dan dengan asumsi $E\left(e_{t}\right)=0$

maka, $\sigma_{s t}^{2}=\operatorname{Var}\left(e_{t} \mid e_{t-1}, e_{t-2, \ldots} \ldots\right)=E\left\{e_{t}^{2} \mid e_{t-1}, e_{t-2}, \ldots \ldots\right\}$

Jika besaran variasi residual dipengaruhi oleh kuadrat residual pada 1 periode sebelumnya, maka kondisi ini dapat dijelaskan dengan Autoregressive Conditional Heteroscedasticity (ARCH) model atas variasi dari residual tersebut. Persamaan pemodelan ARCH order pertama $\mathrm{ARCH}(1)$, atas variasi residual adalah sebagai berikut:

$$
\sigma_{a t}^{2}=\beta_{0}+\beta_{1} e_{t-1}^{2}
$$

\section{Penguiian ARCH effect}

Metodologi dalam mendeteksi keberadaan heteroskedastisitas (volatility clustering), atau ARCH effect, adalah sebagai berikut (Brooks, 2008):

1. Melakukan estimasi regresi linier seperti tampak dalam persamaan berikut:

$$
y_{t}=\alpha_{0}+\alpha_{1} y_{t-1}+\alpha_{2} y_{t-2}+\ldots+\alpha_{n} y_{t-n}+e_{t}
$$

dimana:

$$
\begin{gathered}
y_{t}=\text { pertumbuhan nilai tukar;IHSG;/umlah Unng Beredar } \\
y_{t-1}=\text { tingkat kelambanan }
\end{gathered}
$$

2. Residual yang didapat akan dimanfaatkan dalam persamaan berikut:

$$
\tilde{e}_{t}^{2}=\gamma_{0}+\gamma_{1} \hat{e}_{t-1}^{2}+\gamma_{2} \hat{e}_{t-2 i}^{2}+\cdots+\gamma_{q} \hat{e}_{t-q}^{2}+v_{t}
$$

dimana $v_{t}$ bersifat iid 
1. Menghitung uji statistik yang didefinisikan sebagai $\mathbb{T R ^ { 2 }}$ (jumlah observasi dikalikan dengan koefisien determinasi dari persamaan pada tahap 2), mengikuti distribusi $\boldsymbol{X}^{2}(\boldsymbol{q})$.

2. Hipotesis-hipotesis berkaitan pengujian statistik pada tahap 3 adalah sebagai berikut:

$$
\begin{gathered}
H_{0}: \gamma_{1}=0 \text { dan } \gamma_{2}=0 \text { dan }_{\ldots} \text { dan } \gamma_{q}=0 \ldots \ldots \ldots .(10) \\
H_{1}: \gamma_{1} \neq 0 \text { atau } \gamma_{2} \neq 0 \text { atau ...atau } \gamma_{0} \neq 0 \ldots \ldots \ldots .(11)
\end{gathered}
$$

Bila nilai uji statistik lebih besar daripada nilai kritis pada distribusi $x^{2}$, maka hipotesis nol ditolak.

\section{Generalized Autoregressive Conditional Heteroscedasticity (GARCH)}

Bollerslev (1986) memperkenalkan suatu teknik pemodelan volatilitas, sebagai bentuk ekstensi dari model ARCH - Engle (1982), yaitu Generalized Autoregressive Conditional Heteroscedasticity (GARCH). Persamaan variasi residual dalam pemodelan GARCH adalah sebagai berikut:

$$
\sigma_{a t}^{2}=\beta_{0}+\beta_{1} e_{t-1}^{2}+\beta_{2} \sigma_{s t-1}^{2}
$$

Persamaan di atas adalah model $\operatorname{GARCH}(1,1)$, yang merupakan representasi dari ARMA $(1,1)$, untuk variasi residual. Keunggulan teknik GARCH dalam memodelkan variasi residual dibandingkan dengan ARCH adalah lebih sederhana (parsimony), dan sangat kecil kemungkinannya untuk menghasilkan prediksi variasi dengan besaran negatif.

Sementara itu, besaran uncoditional variance dari $\bar{E}_{\mathrm{t}}$ dihitung dengan formula sebagai berikut:

$$
\operatorname{Var}\left(e_{t}\right)=\frac{\beta_{0}}{1-\left(\beta_{1}+\beta_{2}\right)}
$$

Variasi residual yang diprediksikan kemudian menjelaskan volatilitas dari variabel yang dalam pengamatan. Semakin tinggi nilai variasinya, maka akan semakin tinggi volatilitasnya. Dalam konsep finansial, tingginya volatilitas atas suatu variabel, dapat mencerminkan tingginya resiko investasi pada variabel tersebut. 
Selanjutnya, dikarenakan model yang akan diestimasi tersebut tidak lagi mengikuti pola yang linier, maka teknik OLS tidak lagi sesuai, melainkan Maximum Likelihood (MLE). Spesifikasi model untuk mean dan variasi residual dengan memanfaatkan teknik $\mathrm{AR}(1)$ - $\mathrm{GARCH}(1,1)$ adalah sebagai berikut:

$$
\begin{gathered}
y_{t}=\alpha_{0}+\alpha_{1} y_{t-1}+e_{t,} \quad \mathrm{e}_{t} \sim N\left(0, \sigma_{t}^{2}\right) \\
\sigma_{t}^{2}=\beta_{0}+\beta_{1} e_{t-1}^{2}+\beta_{2} \sigma_{t-1}^{2}+\nu_{t} \ldots
\end{gathered}
$$

Sedangkan fungsi log-likelihood yang akan dimaksimalkan adalah sebagai berikut:

$$
L=-\frac{T}{2} \log (2 \pi)-\frac{1}{2} \sum_{t=1}^{T} \log \left(\sigma_{t}^{2}\right)-\frac{1}{2} \sum_{t=1}^{T} \frac{\left(y_{t}-\alpha_{0}-\alpha_{1} y_{t-1}\right)^{2}}{\sigma_{t}^{2}}
$$

\section{Vector Autoregression (VAR)}

Hubungan saling mempengaruhi antara beberapa variabel dalam pengamatan, dapat dijelaskan dengan teknik pemodelan Vector Autoregression (VAR). Keunggulan teknik pemodelan ini adalah kemampuannya untuk menganalisa dampak dinamis gangguan acak dalam suatu sistem variabel. Singkatnya, model VAR akan memperlakukan setiap variabel endogen sebagai fungsi dari nilai lampau dari tiap variabel endogen lainnya dalam suatu sistem vektor.

Representasi model VAR adalah sebagai berikut:

$$
y_{t}=A_{1} y_{t-1}+\cdots+A_{p} y_{t-p}+B x_{t}+e_{t}
$$

dimana $\boldsymbol{y}_{\boldsymbol{t}} \boldsymbol{y}_{\boldsymbol{t}}$ adalah sejumlah vektor dari variabel endogen, $\boldsymbol{x}_{\boldsymbol{t}} \boldsymbol{x}_{\boldsymbol{t}}$ adalah vektor dari variabel eksogen, sedangkan $\boldsymbol{A}_{\mathbb{1}} \boldsymbol{A}_{\mathbf{1}}, \boldsymbol{A}_{\boldsymbol{p}}, \boldsymbol{A}_{p}$ dan $\boldsymbol{B}$ adalah matriks dari koefisien yang akan diestimasi.

Keunggulan lain dari pemodelan VAR adalah impulse response dan variance decomposition. Dengan memanfaatkan impulse response, dapat diketahui dinamika suatu variabel sebagai akibat dari adanya perubahan dari variabel lain dalam sistem VAR. Sedangkan variance decomposition dapat memperlihatkan besaran kontribusi dari tiap variabel dalam mempengaruhi suatu variabel dalam sistem VAR. 
Dengan memanfaatkan set data dari volatilitas atas pertumbuhan variabelvariabel: nilai tukar Rupiah atas US Dollar (VER) dan Indeks Harga Saham Gabungan (VJCI) dalam skema VAR, dengan tingkat kelambanan tertentu, maka persamaannya dapat ditulis sebagai berikut:

$$
\begin{aligned}
V E R_{1 t} & =\alpha+\sum_{j=1}^{k} \beta_{j} V E R_{t-j}+\sum_{j=1}^{k} Y_{j} V J C I_{t-j}+u_{1 t} \\
V J C I_{1 e} & =\alpha^{t}+\sum_{j=1}^{k} \gamma_{j} V J C I_{t-j}+\sum_{j=1}^{k} \theta_{j} V E R_{t-j}+u_{2 t}
\end{aligned}
$$

\section{HASIL DAN PEMBAHASAN}

Pengujian Stasioneritas Data (Augmented Dickey Fuller test)

Hasil pengujian stasioneritas data pertumbuhan nilai tukar Rupiah terhadap US Dollar (ER) adalah sebagai berikut (t-stat dalam kurung):

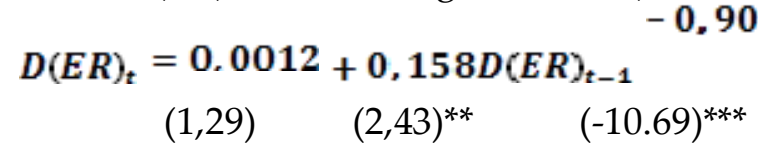

ADF test stat $=-10,69 * * *$

Keterangan: ${ }^{* *},{ }^{* * *}$ berturut-turut signifikan pada $\alpha=5 \%$ dan $w=1 \%$ Hasil pengujian stasioneritas data pertumbuhan IHSG (JCI) adalah sebagai berikut (t-stat dalam kurung):

$$
\begin{aligned}
& D(J C)_{t}=0,0039-0,803 J C I_{t-1} \\
& (2,01)^{* *} \quad(-11,75)^{* * *} \text { ADF } \\
& \text { test stat }=-11,75^{* * *}
\end{aligned}
$$

Keterangan: ${ }^{*},{ }^{* * *}$ berturut-turut signifikan pada $\alpha=10 \%$ dan $\alpha=1 \%$ Hasil-hasil pengujian stasioneritas diatas menunjukkan bahwa variabelvariabel pertumbuhan, yaitu ER dan JCI telah stasioner pada tingkat level.

Hasil Pemodelan Volatilitas dengan GARCH(1,1)

Hasil pemodelan volatilitas pertumbuhan nilai tukar Rupiah terhadap US Dollar (ER) dengan memanfaatkan teknik pemodelan GARCH(1,1) adalah sebagai berikut (z-stat dalam kurung):

$$
\sigma_{e_{t}}^{2}=9,84.10^{-6}+0.52 e_{t-1}^{2}+0,44 \sigma_{e_{t-1}^{2}}^{2}
$$

QE Journal | Vol.06 - No. 03 December 2017 - 165 


$$
(1,99)^{* *} \quad(3,49)^{* * *} \quad(5,00)^{* * *}
$$

Keterangan: ${ }^{* *}$ signifikan pada $\alpha=1 \%$ 
Kemudian, ilustrasi atas prediksi volatilitas ER (VER) hasil estimasi pemodelan diatas adalah sebagai berikut:

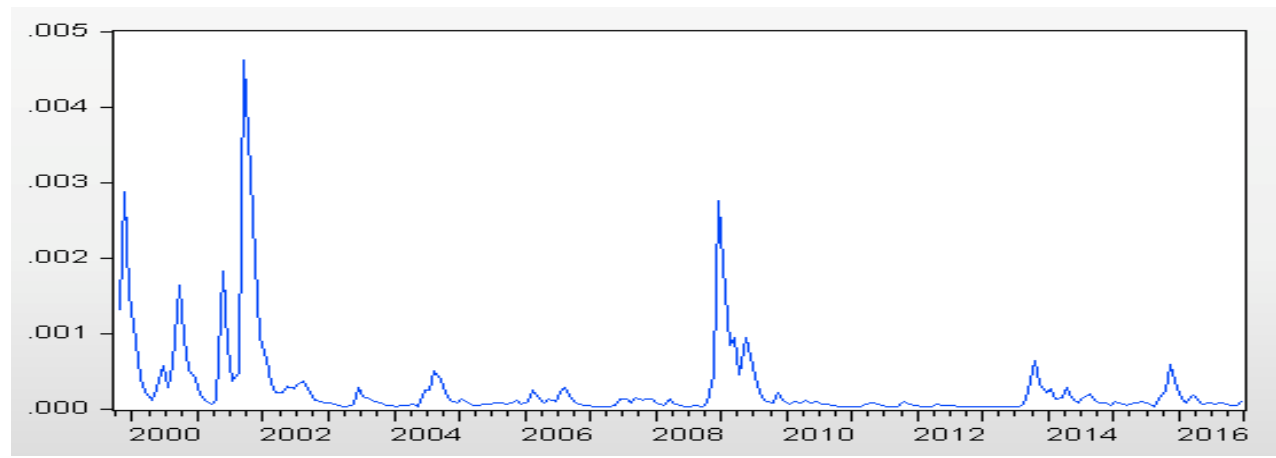

Sumber: Perhitungan Penulis

Gambar 4. Volatilitas Antar Waktu dari ER (VER)

Hasil pemodelan volatilitas pertumbuhan Indeks Harga Saham Gabungan (JCI) dengan memanfaatkan teknik pemodelan $\mathrm{GARCH}(1,1)$ adalah sebagai berikut (z-stat dalam kurung):

$$
\begin{aligned}
\sigma_{e_{\pi}^{2}}^{2}= & 7.18 \cdot 10^{-6}+0,07 e_{t-1}^{2}+0,91 \sigma_{e_{t-1}}^{2} \\
& (0,62) \quad(2,01)^{* *} \quad(19,21)^{* * *}
\end{aligned}
$$

Keterangan: ${ }^{* *}, * * *$ berturut-turut signifikan pada $a=5 \%$ dan $w=1 \%$

Kemudian, ilustrasi atas prediksi volatilitas JCI (VJCI) hasil estimasi pemodelan diatas adalah sebagai berikut:

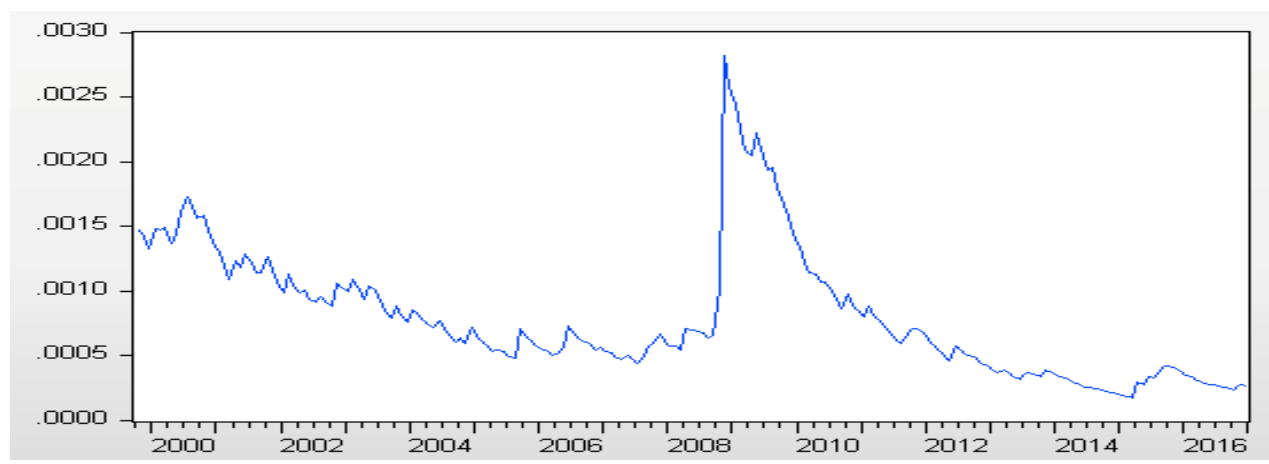

Sumber: Perhitungan Penulis

Gambar 5. Volatilitas Antar Waktu dari JCI (VJCI)

Hasil Permodelan Transmisi Volatilitas dengan Vector Autoregression 
Pada bagian ini akan diperlihatkan hasil estimasi transmisi volatilitas antara variabel-variabel dalam pengamatan, yaitu volatilitas nilai tukar Rupiah atas US Dollar (VER) dan volatilitas IHSG (VJCI. Hasil estimasi pemodelan transmisi volatilitas dengan memanfaatkan teknik pemodelan VAR adalah sebagai berikut (t-stat dalam kurung):

Tabel 1. Hasil Estimasi Pemodelan Transmisi Volatilitas dengan VAR

\begin{tabular}{lrr}
\hline & \multicolumn{3}{c}{ Dependent Variable } \\
& ER & \multicolumn{1}{c}{ JCI } \\
\hline ER(-1) & 0.069783 & 0.365345 \\
ER(-2) & {$[1.02]$} & {$[2.22]^{* * *}$} \\
& -0.128765 & -0.056061 \\
JCI(-1) & {$[-2.09]^{* *}$} & {$[-0.38]$} \\
& -0.190699 & 0.248953 \\
JCI(-2) & {$[-6.30]^{* * *}$} & {$[3.43]^{* * *}$} \\
& -0.0641 & 0.029179 \\
C & {$[-1.94]^{* *}$} & {$[0.37]$} \\
& 0.002579 & 0.003127 \\
R-squared & {$[3.02]^{* * *}$} & {$[1.52]^{*}$} \\
Adj. R-squared & 0.255314 & 0.064542 \\
Sum sq. resids & 0.240495 & 0.045926 \\
S.E. equation & 0.027461 & 0.158446 \\
F-statistic & 0.011689 & 0.028076 \\
Log likelihood & 17.22812 & 3.466985 \\
Akaike AIC & 626.7524 & 446.2312 \\
Schwarz SC & -6.036431 & -4.283798 \\
Mean & -5.955657 & -4.203024 \\
dependent & & \\
S.D. dependent & 0.001236 & 0.004811 \\
S. & 0.013412 & 0.028744 \\
\hline
\end{tabular}

Keterangan: ${ }^{*},{ }^{* *}$, dan ${ }^{* * *}$ berturut-turut adalah signifikan pada $\alpha=10 \%, \alpha=5 \%$, dan $\mathbb{Q}=1 \%$

Kemudian dapat dilihat output impulse response dari estimasi VAR, sebagai berikut: 
Response to Cholesky One S.D. Innovations \pm 2 S.E.

Response of ER to ER

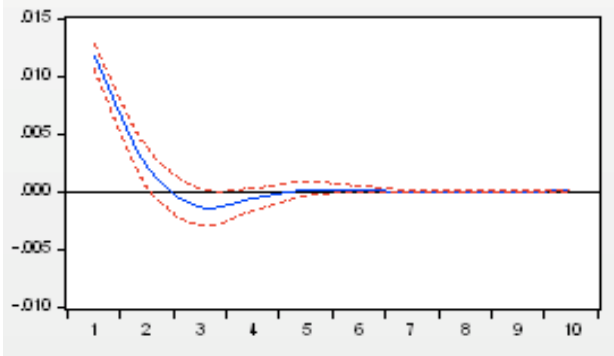

Resporse of JCI to ER

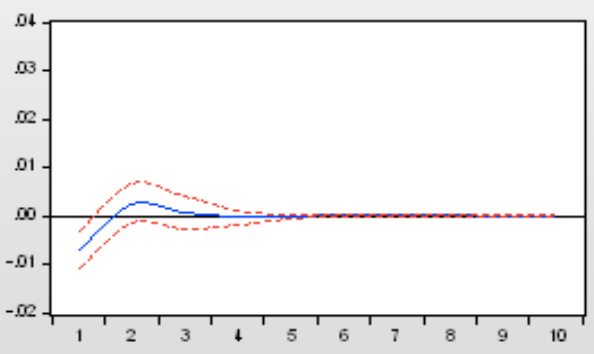

Resporse of ER to JCl

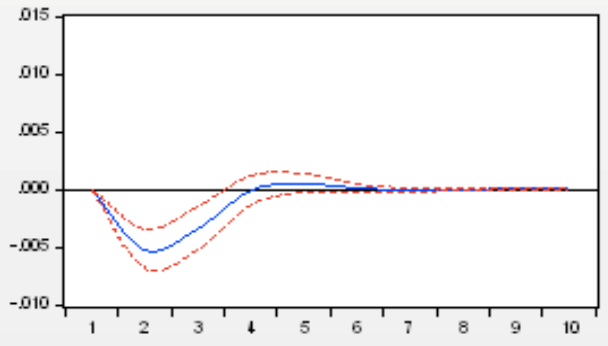

Response of $\mathrm{JCl}$ to $\mathrm{JCl}$

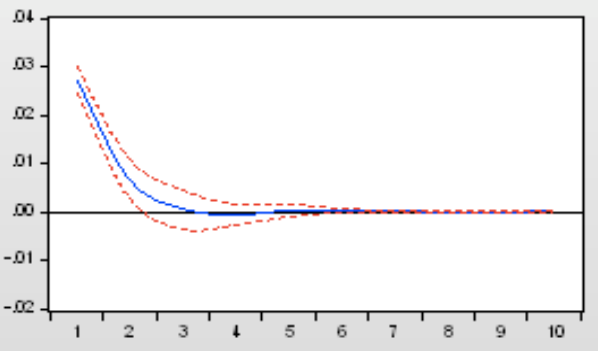

Gambar 6. Impulse Response

Sedangkan output variance decomposition untuk VER dari estimasi VAR adalah sebagai berikut:

Tabel 2. Variance Decomposition untuk VER

\begin{tabular}{cccc}
\hline \hline Period & S.E. & ER & JCl \\
\hline \hline 1 & 0.011689 & 100.0000 & 0.000000 \\
2 & 0.012966 & 84.00198 & 15.99802 \\
3 & 0.013476 & 78.83680 & 21.16320 \\
4 & 0.013492 & 78.87901 & 21.12099 \\
5 & 0.013502 & 78.77119 & 21.22881 \\
6 & 0.013504 & 78.77127 & 21.22873 \\
7 & 0.013504 & 78.76744 & 21.23256 \\
8 & 0.013504 & 78.76694 & 21.23306 \\
9 & 0.013504 & 78.76689 & 21.23311 \\
10 & 0.013504 & 78.76686 & 21.23314 \\
\hline \hline
\end{tabular}

Berdasarkan Tabel 2. didapat kesimpulan bahwa kontribusi rata-rata volatilitas IHSG (VJCI) selama 10 bulan terhadap pergerakan volatilitas nilai tukar Rupiah atas US Dollar (VER) adalah sebesar 16,44\%. 
Output variance decomposition untuk VJCI dari estimasi VAR adalah sebagai berikut:

Tabel 3. Variance Decomposition untuk VJCI

\begin{tabular}{cccc}
\hline \hline Period & S.E. & ER & $\mathrm{JCl}$ \\
\hline \hline 1 & 0.011689 & 6.174767 & 93.82523 \\
2 & 0.012966 & 6.554495 & 93.44550 \\
3 & 0.013476 & 6.586168 & 93.41383 \\
4 & 0.013492 & 6.602515 & 93.39748 \\
5 & 0.013502 & 6.609114 & 93.39089 \\
6 & 0.013504 & 6.608954 & 93.39105 \\
7 & 0.013504 & 6.609229 & 93.39077 \\
8 & 0.013504 & 6.609227 & 93.39077 \\
9 & 0.013504 & 6.609236 & 93.39076 \\
10 & 0.013504 & 6.609237 & 93.39076 \\
\hline \hline
\end{tabular}

Berdasarkan Tabel 3. didapat kesimpulan bahwa kontribusi rata-rata volatilitas nilai tukar Rupiah atas US Dollar (VER) selama 10 bulan terhadap pergerakan volatilitas IHSG (VJCI) adalah sebesar 6,56\%.

\section{SIMPULAN}

Beberapa hal yang dapat disimpulkan dari penelitian ini adalah sebagai berikut:

1. Volatilitas nilai tukar Rupiah terhadap US Dollar memiliki pengaruh yang signifikan terhadap pergerakan volatilitas IHSG, setidaknya apabila dipantau selama 1 bulan sebelumnya. Guncangan negatif dalam bentuk depresiasi nilai tukar Rupiah terhadap US Dollar akan direspon 1 bulan berikutnya dengan guncangan positif pada IHSG. Hal ini terindikasi disebabkan karena meningkatnya permintaan atas saham-saham di Bursa Efek Indonesia oleh investor asing yang menguasai lebih dari $60 \%$ asset finansial di pasar modal Indonesia.

2. Volatilitas IHSG secara signifikan mempengaruhi volatilitas nilai tukar Rupiah terhadap US Dollar. Guncangan positif dalam bentuk peningkatan pertumbuhan IHSG akan direspon dengan terapresiasinya nilai tukar Rupiah terhadap US Dollar pada 1 dan 2 bulan berikutnya. Hal ini disebabkan karena peningkatan kinerja emitten secara agregat di Bursa Efek Indonesia (BEI) akan berkontribusi terhadap 
meningkatnya permintaan atas saham-saham di BEI. Pada kesempatan berikutnya, kondisi tersebut direspon dengan terjadinya apresiasi pada nilai tukar Rupiah terhadap US Dollar melalui transmisi meningkatnya permintaan atas Rupiah.

3. Kontribusi pergerakan IHSG terhadap pergerakan nilai tukar Rupiah terhadap US Dollar lebih tinggi daripada sebaliknya, yaitu berturut- turut $16,44 \%$ dan $6,56 \%$. Kesimpulan yang didapat adalah temuan dalam kajian ini lebih cenderung mengaplikasikan konsep portfolio balanced theory, dimana kinerja pasar modal cenderung memiliki pengaruh terhadap kinerja nilai tukar.

\section{DAFTAR PUSTAKA}

Abdalla, I.S.A. and Murinde, V. (1997) Exchange Rate and Stock Price Interactions in Emerging Markets: Evidence on India, Korea, Pakistan and the Philippines, Applied Financial Economics, 7, 25-35.

Ajayi, R.A. and Mougoue, M. (1996) On the Dynamic relation between stock prices and exchange rates, The Journal of Financial Research, 14(2), 193-207.

Amihud, Y., 1994, Exchange rates and the valuation of equity shares, in: Amihud, Y., Levich, R.M. (eds) Exchange Rate and Corporate Performance, New York: Irwin

Bahmani-Oskooee, M. and Sohrabian, A. (1992) Stock Prices and the Effective Exchange Rate of the Dollar, Applied Economics, 24, 45964 .

Bartov, E. and Bohnar, G. (1994) Firm valuations, earnings expectations and the exchange rate exposure effect, Journal of Finance, 49, 1755-1785.

Caporale, G.M., Pittis, N \& Spagnolo, N. 2002, Testing for Causality-inVariance: An Application to the East Asian Markets, International Journal of Finance and Economics, 7, 235-245.

Chen, N.F., Roll, R., and Ross, S. (1986) Economic forces and the stock market, Journal of Business, 59, 383-403.

Chen, N.F., Roll, R., and Ross, S. (1986) Economic forces and the stock market, Journal of Business, 59, 383-403. 
Chiang, T.C., Yang, S.Y \& Wang, T.S. 2000. Stock Return and Exchange Rate Risk: Evidence from Asian Stock Markets Based on a Bivariate GARCH Model, International Journal of Business, 5(2).

Dhornbush, R. and Fischer, S. (1980) Exchange rates and the current account, American Economic Review, 70, 960-71

Fang, W. (2002) The effects of currency depreciation on stock returns: evidence from five East Asian economies, Applied Economics Letters, 9, 195-99.

Granger, C.J., Huang, B., and Yang, C. (2000) A Bivariate Causality between Stock Prices and Exchange Rates: Evidence from Recent Asian Flu, Quarterly Review of Economics and Finance, 40, 337-354.

Horobet, A., and Ilie, L., (2007) On the Dynamic link between stock prices and exchange rates: evidence from Romania, working papers, Munich Personal RePEc Archive.

Kwon, C. and Shin, T. (1999) Cointegration and causality between macroeconomic variables and stock market returns, Global Finance Journal, 10(1), 71-81.

Mishra, A.K. (2004) Stock Market and Foreign Exchange Market in India: Are They Related? South Asia Economic Journal, 5, 209-232.

Morales, L \& O'Donnell, M. 2006, Volatility Spillovers between Stock Prices and Excnge Rates: Empirical Evidence from Six APEC Economies, Conference Papers. School of Accounting and Finance. Dublin Institute of Technology

Mukherjee, T. and Naka, A. (1995) Dynamic relations between macroeconomic variables and Japanese stock market: an application of a vector error correction model, The Journal of Financial Research, 18(2), 223-237.

Murinde, V., and Poshakwale, S., (2004) Exchange Rate and Stock Price Interactions in European Emerging Financial Markets Before and After the Euro, working paper, Birmingham Business School, University of Birmingham. 
Nieh, C., and Lee, C. (2001) Dynamic Relationship between Stock Prices and Exchange Rates for G7 Countries, Quarterly Review of Economics and Finance, 41, 477-490.

Obben, J, Pech, A., and Shakur, S., 2007, Analysis of the relationship between the share market performance and exchange rates in New Zealand: a cointegrating var approach, working paper, Massey University

Phylaktis, K., and Ravazzolo, F. (2005) Stock Prices and Exchange Rate Dynamics, Journal of International Money and Finance, 24, 10311053.

Tabak, B. (2006) The dynamic relationship between stock prices and exchange rates:evidence for Brazil, working paper, Banco Central Do Brazil.

Wickremasinghe, G., 2006, Dynamic Relations between Stock Prices and Exchange Rates in Sri Lanka: Some Empirical Evidence, working paper, Victoria University, Australia.

Wongbangpo, P. and Sharma, S. (2002) Stock market and macroeconomic fundamental dynamic interactions: ASEAN-5 countries, Journal of Asian Economics, 13, 27-51.

Wu, Y. (2000) Stock Prices and Exchange Rates in a VEC Model - The Case of Singapore in the 1990s, Journal of Economics and Finance, 24, 260274 .

Yang, S-Y., Doong, S-C. 2004, Price and Volatility Spillovers between Stock Prices and Exchange Rates: Empirical Evidence from the G-7 Countries, International Journal of Business and Economics, vol.3, no.2, 139-153.

Yong, O.B., and Isa, Z.B. (2000) Exchange Rate Changes and Stock Market Reactions: A Special Case of Currency Depreciation and its Influence on the local stock market: The Malaysian Experience, Banker's Journal Malaysia, No.113, 56-63..

QE Journal | Vol.06 - No. 03 December 2017 - 172 